\title{
The Contribution of Synchrotron Light for the Characterization of Atmospheric Mineral Dust in Deep Ice Cores: Preliminary Results from the Talos Dome Ice Core (East Antarctica)
}

\author{
Giovanni Baccolo ${ }^{1,2, *(1)}$, Giannantonio Cibin ${ }^{3}$, Barbara Delmonte ${ }^{1}$, Dariush Hampai ${ }^{4}$ (D), \\ Augusto Marcelli ${ }^{4,5}$ (D), Elena Di Stefano ${ }^{1,2,6}$, Salvatore Macis ${ }^{4,7}$ and Valter Maggi ${ }^{1,2}$ \\ 1 Environmental and Earth Sciences Department, University Milano-Bicocca, 20126 Milano, Italy; \\ barbara.delmonte@unimib.it (B.D.); elena.distefano@mib.infn.it (E.D.S.); valter.maggi@unimib.it (V.M.) \\ 2 Milano-Bicocca Section, Istituto Nazionale di Fisica Nucleare, 20126 Milano, Italy \\ 3 Diamond Light Source, Harwell Science and Innovation Campus, Didcot OX11 0DE, UK; \\ giannantonio.cibin@diamond.ac.uk \\ 4 Laboratori Nazionali di Frascati, Istituto Nazionale di Fisica Nucleare, 00044 Frascati, Italy; \\ dariush.hampai@lnf.infn.it (D.H.); augusto.marcelli@lnf.infn.it (A.M.); salvatore.macis91@gmail.com (S.M.) \\ 5 RICMASS, Rome International Center for Materials Science Superstripes, 00185 Roma, Italy \\ 6 Department of Physical, Earth and Environmental Sciences, University of Siena, 53100 Siena, Italy \\ 7 Department of Mathematics and Physics, University Roma-Tor Vergata, 00133 Rome, Italy \\ * Correspondence: giovanni.baccolo@mib.infn.it; Tel.: +39-02-6448-2435
}

Received: 4 July 2018; Accepted: 26 August 2018; Published: 28 August 2018

\begin{abstract}
The possibility of finding a stratigraphically intact ice sequence with a potential basal age exceeding one million years in Antarctica is giving renewed interest to deep ice coring operations. But the older and deeper the ice, the more impactful are the post-depositional processes that alter and modify the information entrapped within ice layers. Understanding in situ post-depositional processes occurring in the deeper part of ice cores is essential to comprehend how the climatic signals are preserved in deep ice, and consequently how to construct the paleoclimatic records. New techniques and new interpretative tools are required for these purposes. In this respect, the application of synchrotron light to microgram-sized atmospheric dust samples extracted from deep ice cores is extremely promising. We present here preliminary results on two sets of samples retrieved from the Talos Dome Antarctic ice core. A first set is composed by samples from the stratigraphically intact upper part of the core, the second by samples retrieved from the deeper part of the core that is still undated. Two techniques based on synchrotron light allowed us to characterize the dust samples, showing that mineral particles entrapped in the deepest ice layers display altered elemental composition and anomalies concerning iron geochemistry, besides being affected by inter-particle aggregation.
\end{abstract}

Keywords: atmospheric mineral dust; ice core; Antarctica; paleoclimate; synchrotron radiation; $\mathrm{X}$-ray absorption near edge spectroscopy; $\mathrm{X}$-ray fluorescence; iron geochemistry

\section{Introduction}

Atmospheric mineral dust is a key component of the Earth climate system. Climate influences the production, transport, and deposition of dust. Conversely, dust affects climate, with direct and indirect effects related to the radiative properties of the atmosphere and of the surfaces where it is deposited, to cloud physics, and to biogeochemistry [1-3]. Paleoclimate archives were essential to reconstruct the past interactions between climate and the global dust cycle. Ice cores showed that a close connection 
exists between them at different spatial and temporal scales: From fast climatic oscillations to the longer glacial/interglacial transitions [4-6]. At present, EPICA Dome C is the Antarctic ice core that allowed for the longest and most detailed climatic reconstruction of the last 800,000 years [7,8], including an accurate record of dust deposition during the last eight climatic cycles [4].

The need for retrieving a deep ice core extending beyond EPICA Dome C and encompassing the so-called Mid Pleistocene revolution is definitely challenging. A key aspect related to signal preservation in the bottom part of the core depends on our understanding of in situ post-depositional processes potentially affecting the original climate related signals [9-11]. Disentangling the latter from the true climatic signals embedded in deep and ancient ice will be stimulating for the field of ice core science, but also for analytical chemistry and ice micro-physics. The processes usually quoted as the most important ones, in relation to the occurrence of post depositional processes in deep ice, are: The evolution of ice crystal fabric, the diffusion and/or relocation of soluble and insoluble impurities, and the interaction with bedrock $[9,10,12]$.

Mineral dust enclosed in the deeper part of ice cores-where the temperature gradient increases and the ice temperature is close to the pressure melting point - is known to be affected by relocation processes. Impurity relocation occurs because of the exclusion of solid impurities from the ice lattice during ice grain recrystallization. A direct consequence of this process is the enrichment of particles in the unfrozen liquid film that separates grain boundaries, and the formation of dust aggregates of different sizes, as first noticed in the EPICA Dome C ice cores below about $2900 \mathrm{~m}$ depth [11]. Additional processes potentially affecting the dust record in the bottom part of deep ice cores are related to the presence of inclusions from the bedrock, which makes atmospheric dust particles more difficult to recognize and analyze [10].

In this work, we present preliminary results about the atmospheric mineral dust record from the deep part of the Talos Dome ice core (TALDICE). We show that in addition to the aggregation of mineral particles, the dust entrapped in deep ice is also affected by evident compositional changes, in particular concerning iron geochemistry. These findings are coherent with early observations on the deeper part of the EPICA Dome C ice core, where evidence of chemical alteration of insoluble particles were shown by De Angelis and coauthors [10]. Despite being preliminary, our results show that synchrotron radiation-based techniques are extremely promising for ice core science.

\section{Materials and Methods}

\subsection{The Talos Dome Ice Core}

The Talos Dome ice core-also known as TALDICE-was drilled from the homonymous ice dome located at the NE periphery of the East Antarctic Ice Sheet (EAIS), close to Victoria Land and the Ross Sea [13]. It is $1620 \mathrm{~m}$ long and can be divided into two parts. The upper part extends from the surface to a depth of $1440 \mathrm{~m}$, it was recognized to be stratigraphically intact and corresponds to the last $150 \mathrm{kyr}$ [14]. The lower section ranges from 1440 to the end of the core; its integrity has not been assessed because of relevant concerns about the influence of the irregular topography of the underlying bedrock that characterizes the Talos Dome area [15]. To the aims of this study, two sets of samples were considered, consisting of 4 samples each: The first one (from TD1 to TD4) is composed by samples retrieved from the upper part of the core that is climatically intact [16], the second group (from TD5 to TD8) is composed by samples from the deeper part that corresponds to the undated section (below $1440 \mathrm{~m}$ ). Samples were prepared using ice strips dedicated to dust analysis. Ice core strips were decontaminated and treated for the successive analyses in accordance to a well-established procedure [17]. After melting, decontaminated meltwater was divided into two aliquots, one for Coulter counter analysis, one for synchrotron light-based measurements. Details about the samples are found in Table 1. 
Table 1. Details about the samples from the Talos Dome ice core considered in this work. Depth refers to the depth along the core with respect to ground level; ice age (expressed in terms of thousands of years before 1950, i.e., kyr BP) was retrieved from the AICC2012 chronology developed for some Antarctic ice cores $[15,16]$; the dust concentration was determined through Coulter counter analysis. MIS2 corresponds to Marine Isotopic Stage 2: It is the coldest and final phase of the last glacial period, it occurred between 30 and 18 kyr BP.

\begin{tabular}{ccccc}
\hline Sample & Depth $(\mathbf{m})$ & Ice Age (kyr BP) & Climatic Period & Dust Conc. $\left(\right.$ ng $_{\text {dust }} \cdot \mathbf{g}^{-\mathbf{1}}$ ice \\
\hline TD1 & 185 & 2.0 & Holocene & $27 \pm 5$ \\
TD2 & 241 & 2.8 & Holocene & $27 \pm 2$ \\
TD3 & 857 & 20.2 & MIS2 & $479 \pm 5$ \\
TD4 & 873 & 21.8 & MIS2 & $512 \pm 6$ \\
TD5 & 1530 & Unkn. & Deep Part & $230 \pm 10$ \\
TD6 & 1554 & Unkn. & Deep Part & $133 \pm 8$ \\
TD7 & 1595 & Unkn. & Deep Part & $25.2 \pm 0.7$ \\
TD8 & 1613 & Unkn. & Deep Part & $35 \pm 3$ \\
\hline
\end{tabular}

\subsection{Coulter Counter}

The Coulter counter technique is well-established dealing with ice cores [18]. It allows for the detection of micrometric insoluble mineral particles suspended within a liquid water solution. It employs the impedance generated by the flowing of a solid particle through a narrow orifice where an electric voltage is applied. Further details about the technique and about the procedure are found in previous publications [18]. For this work, a $30 \mu \mathrm{m}$ orifice was used and particles between 0.6 and $18 \mu \mathrm{m}$ (divided into 400 channels) were detected.

\subsection{Synchrotron Light Measurements}

Two X-ray spectroscopy techniques based on synchrotron radiation were applied to the atmospheric dust samples from the Talos Dome ice core: $1 \mathrm{X}$-ray fluorescence (XRF); and 2 X-ray absorption near edge structure spectroscopy (XANES). These tools provide complementary and diverse pieces of information [19]. Through XRF, it was possible to assess the elemental composition of the dust particles extracted from the ice core strips; XANES, on the other hand, allowed gathering detailed information about selected elements. In the case of XRF, attention was given to major elements, while in the case of XANES we focused on iron. Both major elements and iron are geochemically relevant. Major elements, i.e., the ones whose oxide mass fraction exceeds $0.1 \%$ of average crustal mass (Na, Mg, Al, Si, K, Ca, Ti, Mn, and Fe), constitute more than 99\% of Earth crust [20]. Because of their abundance, they are relatively easy to determine, but at the same time they allow one to depict a coherent geochemical signature of the considered crustal material. Indeed, they were already used to characterize atmospheric mineral dust from ice cores [21]. Among major elements, Fe is one of the most interesting when considering the interactions between biogeochemistry, dust, and climate. This is because atmospheric dust plays a role in supplying iron to the oceans, where this element is a limiting factor for oceanic bio-productivity [2,22]. Ice cores are important in this context, since they allow reconstructing the variability of these processes on the glacial-interglacial timescale and assessing the role of dust in the global carbon cycle [23,24].

Samples dedicated to synchrotron light measurements were prepared through filtration. After decontamination and melting, mineral dust particles were extracted from meltwater with a filtration system coupled to clean (rinsed with a $3 \% \mathrm{HNO}_{3}$ solution for one month) polycarbonate membranes $(0.45 \mu \mathrm{m}$ pore size) which proved to be sufficiently clean for our purposes [25]. A comparison between the XRF signal related to blank membranes and our samples is shown in Figure 1. It can be appreciated that despite samples consisting a few $\mu \mathrm{g}$ of dust, their signal is at least one order of magnitude higher than the blank one. This means that the contamination in the blank membranes is in the order of few tens of pg for each element. A variable amount of meltwater was filtered for each sample, so as to 
deposit at least 2-3 $\mu \mathrm{g}$ of dust on each membrane. The filtration was carried out using a micro-pipette, transferring meltwater one $\mathrm{mL}$ at a time on the membrane mounted on the filtration system. This step is important since the accumulation of dust particles in the smallest possible area greatly improves the quality of analytical results [26]. Before transferring the meltwater from the original containers to the filtration system, the containers were shaken, so as to mobilize the particles eventually deposited on the bottom of the container. When all the meltwater was transferred, a few $\mathrm{mL}$ of ultrapure water is used to rinse the inner walls of the container tubes to catch the mineral particles that could be attached to them. Rinsing water was then passed to the filtration system using the pipette. This procedure was repeated three times for each sample and also for the preparation of the blanks. After filtration, the membranes were mounted on clean PTFE sample holders and successively analyzed at the B18 beamline of the Diamond Light Source [27].
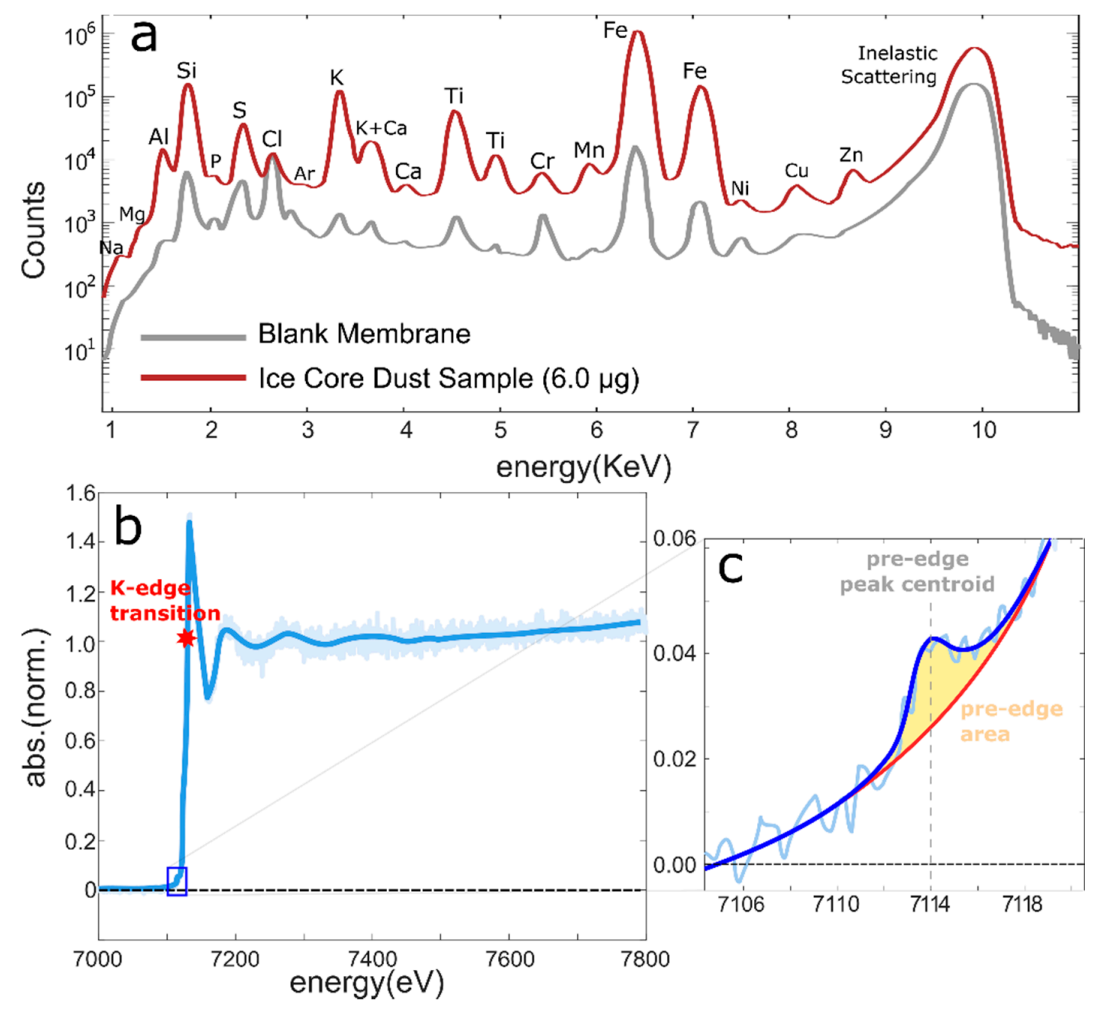

Figure 1. Examples of the results obtained through the application of synchrotron radiation to ice core atmospheric dust samples. Panel (a): An X-ray fluorescence (XRF) spectrum; it is possible to appreciate the difference between a blank membrane and an average dust sample (total mass deposited on the filter $6 \mu \mathrm{g}$ ). Panels $(\mathbf{b}, \mathbf{c})$ show an X-ray absorption near edge structure spectroscopy (XANES) spectrum related to the Fe $\mathrm{K}$ adsorption edge. The red star refers to the position of the edge, identified using the second derivative. In panel (c), an enlargement of the pre-edge region is shown, including a fit of the background (red curve) and of the pre-edge peak (dark blue curve). The two parameters used for the pre-edge analysis are highlighted: The integral area of the pre-edge structure (yellow area) and its centroid energy (vertical dashed line).

A silicon drift detector was used for both XRF and XANES measurements. A complete description of the instrumental setup can be found here [28]. XRF spectra were collected with a $10 \mathrm{keV}$ incident beam and $600 \mathrm{~s}$ acquisition time. XANES was performed on Fe K-edge considering the energy interval between 6900 and $7800 \mathrm{eV}$ and steps of $0.15 \mathrm{eV}$ between each acquisition. Energy was calibrated with repeated measurements of the absorption edge of a metallic Fe foil (7122 eV), additional details are given in previous works $[29,30]$, while explanatory results are presented in Figure 1. 


\section{Results and Discussion}

\subsection{Grain Size Distributions}

The two sets of atmospheric mineral dust samples extracted from the Talos Dome ice core present evident differences in relation to all the variables and parameters considered in this study: Grain size distribution, elemental composition, and iron properties. In Figure 2, it is possible to appreciate the differences characterizing grain size distributions. The first two distributions refer to two samples from the first group considered here, i.e., the one composed by samples obtained from the stratigraphically intact section of the Talos Dome ice core. They display clear differences owing to the different climatic periods during which they were deposited. The sample from the Holocene (Figure 2a) presents low dust concentration ( $27 \mathrm{ng}_{\mathrm{dust}} \cdot \mathrm{g}^{-1}$ ice $)$ and a poor size selection; on the contrary, the sample from MIS2 is more concentrated (479 $\mathrm{ng}_{\text {dust }} \cdot \mathrm{g}^{-1}$ ice) and displays a distribution that is easily fitted by a log-normal equation, ascribable to a prolonged atmospheric transport. These features are well-known for the Talos Dome ice core: They were related to different dust depositional regimes characterizing the site during glacial and interglacial periods [31-33]. What observed in Figure 2c is different with respect to the previous cases. The third distribution concerns a sample from the deep undated part of the ice core. It shows a coarse mode $(4.4 \mu \mathrm{m})$, with limited presence of fine particles. Such features are never encountered when dealing with more superficial sections of Antarctic ice cores, considering either interglacial periods, either glacial ones [34]. The only process that can explain similar features is particle aggregation. Its occurrence was already observed in deep polar ice cores and it was explained as the effect of ice grain growth on mineral dust particles [10,11]. But if such effects on grain size distribution are partially known, much less is understood when pointing attention to dust compositional changes in deep ice.

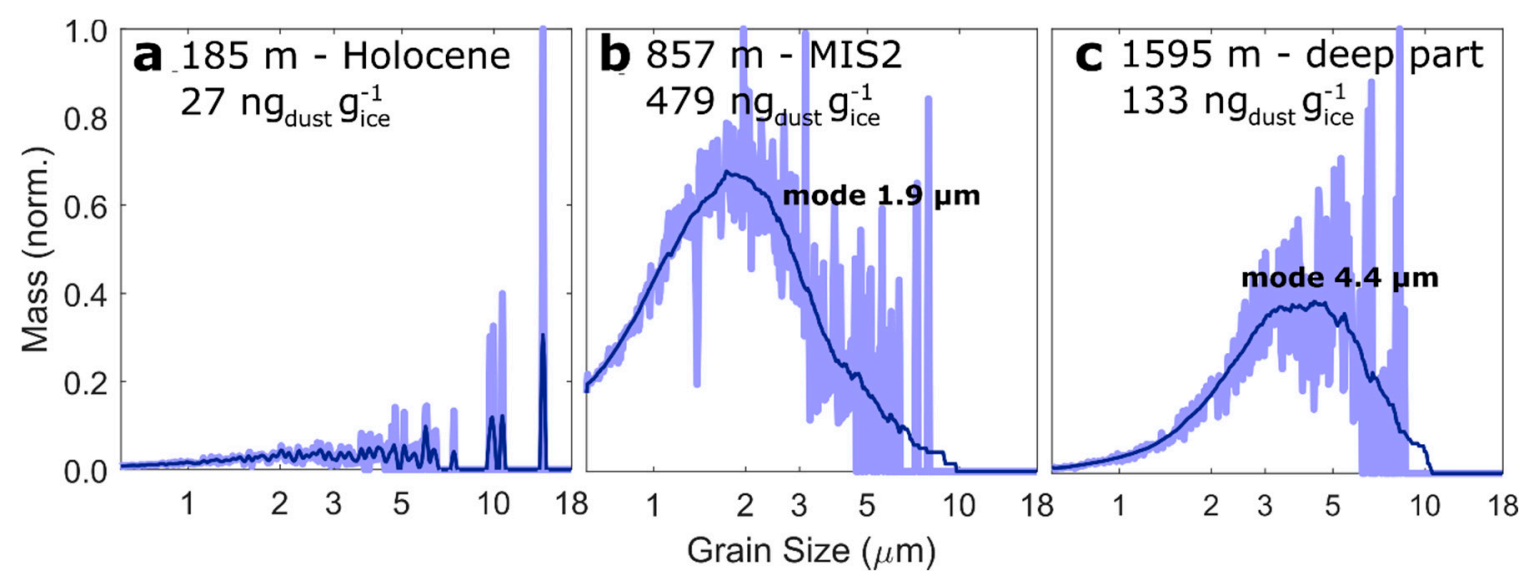

Figure 2. Examples of size distributions determined through Coulter counter of the mineral particles found in ice sections from the Talos Dome ice core. For each sample the depth along the core, the climatic period and the absolute dust concentration are reported. From the left to the right. (a) A sample from the Holocene, showing poor size selection and a large relative contribution from coarse particles; (b) A sample from Marine Isotopic Stage 2 (MIS2, one of the three stages of the last glacial period), in this case size selection is evident and points to a prolonged atmospheric transport; (c) A sample from the deep undated part of the Talos Dome ice core; the coarse modal value and the limited presence of fine particles point to a significant aggregation of mineral particles.

\subsection{Dust Composition}

Data about the major element composition of the Talos Dome ice core samples are fully reported in Table 2, while they are graphically presented in Figure 3. It can be easily appreciated that the samples gathered from the climatically intact sections of the core show different compositional features with respect to the ones from the deeper part. The composition of the shallower samples is similar to the 
Upper Continental Crust reference (UCC, [35]), confirming the crustal origin for the insoluble particles deposited on polar ice sheets. The only significant difference concerns $\mathrm{CaO}$ : The average $\mathrm{CaO}$ content in TD shallow samples is $1.7 \%$, in accordance to what observed at another Antarctic site [21], while the value for average UCC is 3.6\%. Calcium carbonate accounts for a significant fraction of Ca in global crust sediments, but dust transported toward Antarctica from the continental areas of the Southern hemisphere is depleted in carbonate as a consequence of acid-base reactions occurring in the atmosphere during the transport $[36,37]$. Additional differences are appreciated if comparing the four samples constituting this group, for example the variable amount of $\mathrm{Al}$ and $\mathrm{Si}$ oxides. Such variability is not unexpected, since these samples are partly from the current interglacial period (the Holocene) and partly from the last glacial maximum. It is known that the dust sources responsible for the deposition of mineral particles at Talos Dome were different in the two periods, with effects on dust composition [28,38].

Table 2. Major element composition of the samples. Since the total mass of major element oxide represents more than $99 \%$ of average Earth crust composition [20], the total sum was closed to $100 \%$. For each one of the two sample groups (respectively shallow and deep samples) the average composition is also reported (standard deviations in brackets). Upper continental crust (UCC) reference from Rudnick \& Gao [35].

\begin{tabular}{|c|c|c|c|c|c|c|c|c|c|}
\hline Sample & $\mathrm{Na}_{2} \mathrm{O} \%$ & $\mathrm{MgO} \%$ & $\mathrm{Al}_{2} \mathrm{O}_{3} \%$ & $\mathrm{SiO}_{2} \%$ & $\mathrm{~K}_{2} \mathrm{O} \%$ & $\mathrm{CaO} \%$ & $\mathrm{TiO}_{2} \%$ & $\mathrm{MnO} \%$ & $\mathrm{Fe}_{2} \mathrm{O}_{3} \%$ \\
\hline TD1 & 2.0 & 1.5 & 18.6 & 67.9 & 1.9 & 1.3 & 0.8 & 0.05 & 6.1 \\
\hline TD2 & 5.5 & 2.1 & 16.1 & 64.2 & 1.4 & 2.5 & 1.1 & 0.07 & 6.9 \\
\hline TD3 & 2.1 & 6.0 & 21.0 & 61.3 & 1.7 & 1.5 & 1.0 & 0.07 & 5.3 \\
\hline TD4 & 2.4 & 2.1 & 22.2 & 60.2 & 2.0 & 1.6 & 1.5 & 0.11 & 7.8 \\
\hline Average shallow & 3.0 & 2.9 & 19.5 & 63.4 & 1.8 & 1.7 & 1.1 & 0.07 & 6.5 \\
\hline samples & $(1.7)$ & $(2.1)$ & $(2.7)$ & (3.4) & $(0.3)$ & $(0.6)$ & $(0.3)$ & $(0.03)$ & (1.1) \\
\hline TD5 & 2.6 & 0.9 & 21.3 & 65.1 & 2.7 & 0.3 & 0.9 & 0.04 & 6.0 \\
\hline TD6 & 0.8 & 0.6 & 15.7 & 72.7 & 2.4 & 1.1 & 1.2 & 0.04 & 5.6 \\
\hline TD7 & 0.9 & 0.2 & 7.7 & 84.0 & 1.4 & 0.2 & 0.8 & 0.02 & 4.7 \\
\hline TD8 & 2.0 & 0.1 & 7.4 & 80.0 & 1.9 & 0.2 & 1.0 & 0.03 & 7.3 \\
\hline Average deep & 1.6 & 0.5 & 13.0 & 75.4 & 2.1 & 0.4 & 1.0 & 0.03 & 5.9 \\
\hline samples & $(0.9)$ & $(0.4)$ & $(6.7)$ & (8.3) & $(0.6)$ & $(0.4)$ & $(0.2)$ & $(0.01)$ & (1.1) \\
\hline UCC reference & 3.3 & 2.5 & 15.4 & 66.7 & 2.8 & 3.6 & 0.6 & 0.1 & 5.0 \\
\hline
\end{tabular}

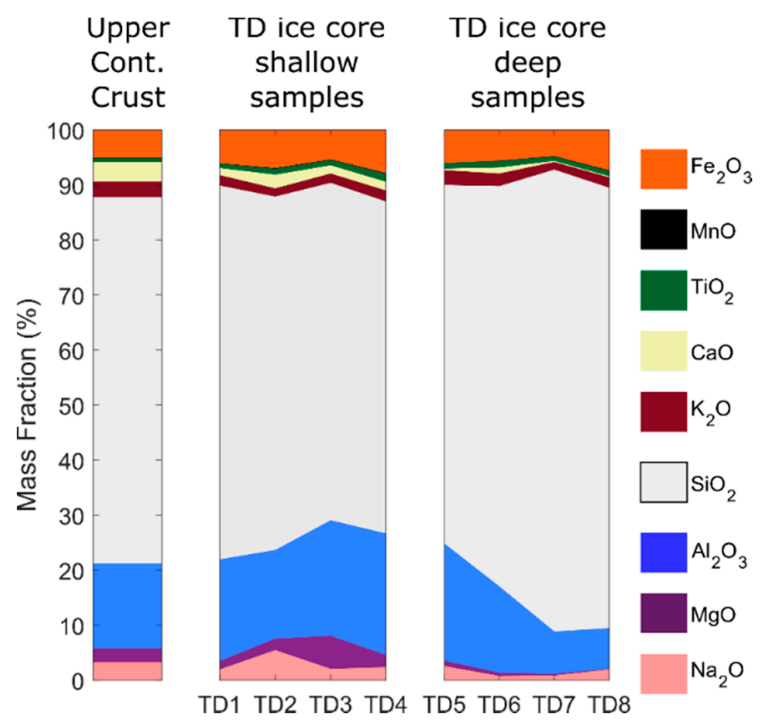

Figure 3. Major element composition of the mineral dust samples extracted from the Talos Dome ice core. From left to right: The UCC reference [35], samples from the shallower section of the Talos Dome ice core, samples from the deeper one. 
A different scenario is found when focusing on the samples from the deeper part of the Talos Dome ice core. In this case, their average composition shows clear dissimilarities with respect to the UCC reference. This is particularly true for $\mathrm{Mg}$ and $\mathrm{Ca}$ oxides. Both are almost absent in the deep samples, with average concentrations of 0.5 and $0.4 \%$, representing respectively $1 / 9$ and $1 / 5$ of UCC composition. These two elements were already recognized as some of the most affected by post-depositional processes in deep ice cores. An increase of the concentration of dissolved $\mathrm{Ca}^{2+}$ and $\mathrm{Mg}^{2+}$ was observed in the deepest sections of the EPICA Dome $\mathrm{C}$ ice core, in association with anomalies concerning sulfates and other dissolved species [10,33]. Considering this context, it is possible to hypothesize that in deep ice mineral particles are subjected to significative chemical transformations. The depletion of $\mathrm{CaO}$ and $\mathrm{MgO}$ in mineral dust from the deeper sections of the Talos Dome ice core and the rise of the dissolved concentration of $\mathrm{Ca}^{2+}$ and $\mathrm{Mg}^{2+}$ in other deep Antarctic ice cores could be explained by a progressive dissolution of the carbonate mineral fraction originally present within the mineral dust particles. In deep ice, the concurrent presence of liquid veins [39] and dust aggregates at grain boundaries [9] and of an acid environment [36], could enhance such dissolution processes. $\mathrm{CaO}$ and $\mathrm{MgO}$ are the two oxides for which these effects are more evident, but it seems that for $\mathrm{Al}_{2} \mathrm{O}_{3}, \mathrm{NaO}$, and $\mathrm{Fe}_{2} \mathrm{O}_{3}$ they could also be active, given their significant depletion in deep samples. As a complementary evidence, the $\mathrm{SiO}_{2}$ fraction of dust particles is larger in the deep part of the Talos Dome ice core than in the shallow one (on average $75 \%$ vs. $63 \%$ ). This is a consequence of the geochemical stability of $\mathrm{SiO}_{2}$ : If the more labile mineral fractions are dissolved, the stable ones increase their relative abundance.

\subsection{Iron Geochemistry}

In Figure 4, the data from Fe-XANES are presented. Figure 4a refers to the absorption spectra and show the transition of Fe K-edge in all the samples. The data used to interpret iron geochemistry were obtained from the analysis of these spectra. Attention was given to different spectral regions: The pre-edge one (Figure $4 \mathrm{~b}$ ) and the position of the main energetic transition edge (Figure $4 \mathrm{c}$ ). Both are sensitive to iron speciation, oxidation, and coordination states [40]. Unfortunately, it was not possible to gather data from mineralogical standards and for this reason we cannot quantitatively assess the mineralogical assemblages that could resemble our results. Such an analysis will be discussed in the near future, but a qualitative look at the spectra is sufficient to reveal that the spectra show some differences. Despite this limitation, it was still possible to extract information about the oxidation and coordination states of our samples, as shown in Figure $4 b, c$. 

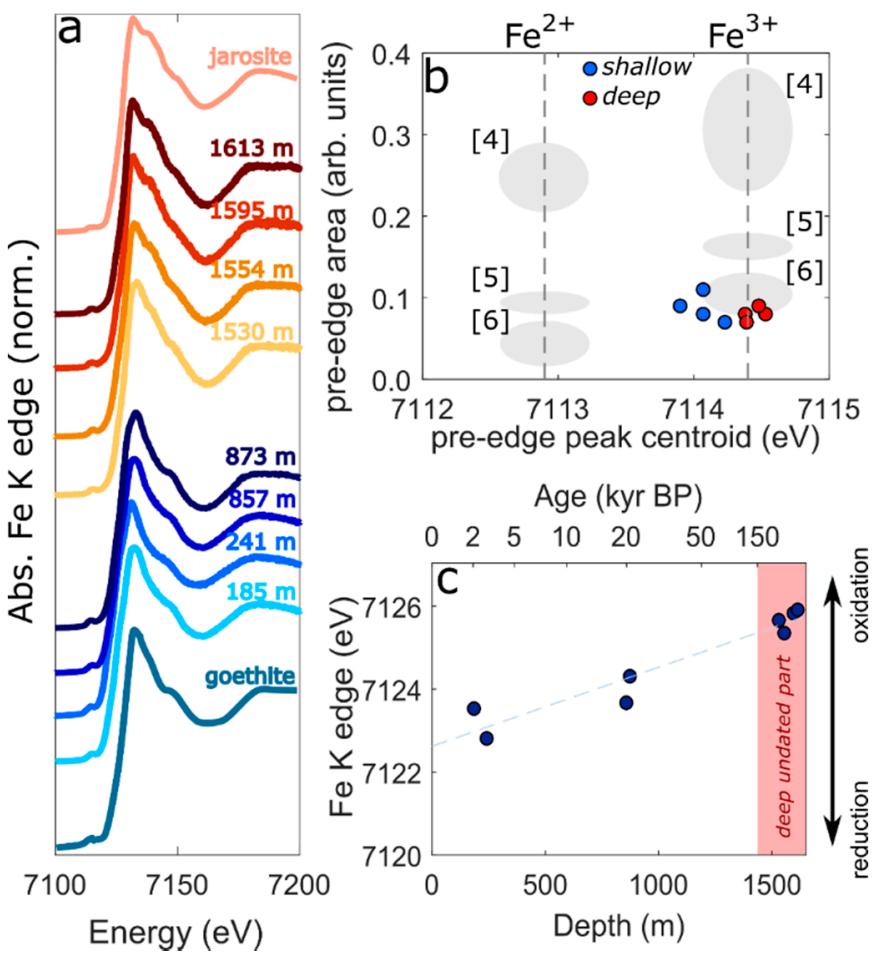

Figure 4. Results from XANES Fe spectroscopy. Panel (a): X-ray absorption spectra at the Fe K-edge. For each spectrum the depth of the considered sample along the Talos Dome ice core is reported. Blue samples are from the intact part of the core. Yellow/orange ones are from the deeper undated part below $1440 \mathrm{~m}$. In addition, two spectra referred to mineral standards are shown: Goethite [41] and jarosite [42], which were retrieved from literature and have to be considered as merely indicative. Panel (b): Pre-edge analysis of the absorption spectra (see also the caption of Figure 1). For each sample, the following variables were considered: The integral area of the pre-edge peak and its centroid energy. Data uncertainties are comparable to the size of the circles. The two-axes domain is presented in accordance to a previously proposed scheme $[43,44]$, where characteristic fields are recognized in relation to iron oxidation (ferrous $\mathrm{Fe}^{2+}$ and ferric $\mathrm{Fe}^{3+}$ ) and coordination (tetrahedral [4], trigonal bipyramidal [5], and octahedral [6], please note that in this case the notation [ . . ] doesn't refer to the cited bibliography but to atomic coordination numbers) states. Panel (c): A comparison between the Fe K-edge energy observed for each sample and their depth along the Talos Dome ice core (ice age is also reported [16]).

Data about the pre-edge region of the spectra-i.e., the integral area of the pre-edge peak and its energy position-were presented using the scheme proposed by Wilke and colleagues [43] and Giuli and coauthors [44]. In that scheme, the two-dimensional space is divided into different domains reflecting the oxidation and coordination states of Fe. Not unexpectedly, all the samples are found near the field of [6] $\mathrm{Fe}^{3+}$ ([6] doesn't refer to bibliography, but to iron coordination number, see the caption of Figure 4 for further details), that is iron in its ferric state with an octahedral geometry. All the most common iron oxides that are found in superficial environments belong to this field, for example goethite, hematite, and ferrihydrite [43], confirming that iron transported in association with atmospheric dust is mainly related to these minerals [45]. Despite all the samples being located near the [6] $\mathrm{Fe}^{3+}$ field, a difference is observed between shallow and deep samples (respectively blue and red dots in Figure $4 \mathrm{~b}$ ). The first ones show a pre-edge energy which is in accordance to a mix of $70 \% \mathrm{Fe}^{3+}$ and $30 \% \mathrm{Fe}^{2+}$, on the contrary the signature of the deep samples reveals a $100 \% \mathrm{Fe}^{3+}$ contribution. The same is supported by Figure 4c, where the position of the K-edge is compared to the depth of the samples along the ice core. The deeper the samples, the more oxidized the iron. This is an additional clue about the effects of post-depositional processes on mineral dust composition in deep ice. Indeed, deep ice sheets are not anoxic environments, the presence of liquid water veins [39] 
and dissolved oxygen [46] could enhance not only the dissolution of specific mineral phases but also their oxidation. XANES spectra of the deeper samples present a spectral feature at about $7140 \mathrm{eV}$, which the shallower samples don't display (see Figure 4a). This is an additional evidence for the occurrence of post-depositional processes, since that feature is typical only in some Fe-sulfates, such as jarosite [42] (Figure 4a). The latter, which presents iron in its [6] Fe ${ }^{3+}$ state, is known to form because of the oxidation and alteration of Fe minerals in acid environments where sulfur-rich fluids and water are present [47]. Sulfates are known for being subjected to heavy post-depositional processes in deep ice sheets $[10,38]$. It was already proposed that in deep ice sulfuric acid could react with mineral phases, enhancing the in-situ production of sulfate salts, as for example $\mathrm{MgSO}_{4}$ [38]. Combining our preliminary evidences about iron speciation and the direct observation of localized sulfate deposits on mineral dust particles in deep ice [10], it is reasonable to hypothesize that the iron fraction of mineral dust entrapped in deep ice is affected by relevant post-depositional processes. Future studies focused on the reconstruction of ice core records about the oxidation of iron in the past climatic periods and on its role in iron biogeochemistry should take these results into account [24,48].

\section{Conclusions and Perspectives}

Although being preliminary, the current work clearly shows the great potential of synchrotron light for the characterization of mineral dust extracted from ice core samples. Combining XRF, XANES, and traditional grain size analysis, it was possible to appreciate significant differences between mineral dust samples retrieved from the shallow part of the Antarctic Talos Dome ice core and from the deep one. It was already known that in deep ice, dust is affected by aggregation and re-location; what is new is that its chemical composition is also influenced by ice depth. Dissolution and oxidation seem to be the most important processes in this context, but further efforts are needed to better comprehend them and to clearly assess the role played by post-depositional process in altering ice core records of atmospheric mineral dust. This is a preliminary work, focused on few samples from a single ice core and on a single K-edge transition. Its main purpose is to demonstrate the potential of such techniques in relation to the future deep ice core drilling projects, where the assessment of the integrity of the climatic signals embedded within the ice stratigraphy will became more and more important.

Author Contributions: A.M. and V.M. conceived the idea of this work. A.M. and G.C. designed the experiments; all the authors prepared the samples and performed the experiments; G.C., D.H. and G.B. analyzed the data; G.B. wrote the paper and interpreted the results.

Acknowledgments: The Talos Dome Ice core Project (TALDICE), a joint European programme, is funded by national contributions from Italy, France, Germany, Switzerland and the United Kingdom. Primary logistical support was provided by PNRA at Talos Dome. This is TALDICE publication no 50. This study has been partially supported by DARA (Dipartimento per gli Affari Regionali e Autonomie of Italian Presidenza del Consiglio dei Ministri) in the framework of the MIAMI (Monitoraggio dell'Inquinamento Atmosferico della Montagna Italiana) project. Synchrotron radiation measurements were carried out in the framework of Proposals NT1984 at the Diamond Light Source.

Conflicts of Interest: The authors declare no conflict of interest.

\section{References}

1. Arimoto, R. Eolian dust and climate: Relationships to sources, tropospheric chemistry, transport and deposition. Earth Sci. Rev. 2001, 54, 29-42. [CrossRef]

2. Jickells, T.D.; An, Z.S.; Andersen, K.K.; Baker, A.R.; Bergametti, G.; Brooks, N.; Cao, J.J.; Boyd, P.W.; Duce, R.A.; Hunter, K.A.; et al. Global iron connections between desert dust, ocean biogeochemistry and climate. Science 2005, 308, 67-71. [CrossRef] [PubMed]

3. Maher, B.A.; Prospero, J.M.; Mackie, D.; Gaiero, D.; Hesse, P.P.; Balkanski, Y. Global connections between aeolian dust, climate and ocean biogeochemistry at the present day and at the last glacial maximum. Earth-Sci. Rev. 2010, 99, 61-97. [CrossRef] 
4. Lambert, F.; Delmonte, B.; Petit, J.R.; Bigler, M.; Kaufmann, P.R.; Hutterli, M.A.; Stocker, T.F.; Ruth, U.; Steffensen, J.P.; Maggi, V. Dust-climate couplings over the past 800.000 years from the EPICA Dome C ice core. Nature 2008, 452, 616-619. [CrossRef] [PubMed]

5. Fischer, H.; Fundel, F.; Ruth, U.; Twarloh, B.; Wegner, A.; Udisti, R.; Becagli, S.; Castellano, E.; Morganti, A.; Severi, M.; et al. Reconstruction of millenial changes in dust emission, transport and regional sea ice coverage using the depp EPICA ice cores from the Atlantic and Inidian Ocean secont of Antarctica. Earth Planet. Sci. Lett. 2007, 260, 340-354. [CrossRef]

6. Wegner, A.; Fischer, H.; Delmonte, B.; Petit, J.R.; Erhardt, T.; Ruth, U.; Svensson, A.; Vinther, B.; Miller, H. The role of seasonality of mineral dust concentration and size on glacial/interglacial dust changes in the EPICA Dronning Maud Land ice core. J. Geophys. Res. 2015, 120. [CrossRef]

7. Epica Community Members. Eight glacial cycles from an Antarctic ice core. Nature 2004, 429, $623-628$. [CrossRef] [PubMed]

8. Jouzel, J.; Masson-Delmotte, V.; Cattani, O.; Dreyfus, G.; Falourd, S.; Hoffmann, G.; Minster, B.; Nouet, J.; Barnola, J.M.; Chappellaz, J.; et al. Orbital and millennial Antarctic climate variability over the past 800,000 years. Nature 2007, 317, 793-796. [CrossRef] [PubMed]

9. Faria, S.H.; Freitag, J.; Kipstul, S. Polar ice structure and the integrity of ice-core paleoclimate records. Quat. Sci. Rev. 2010, 29, 338-351. [CrossRef]

10. De Angelis, M.; Tison, J.L.; Morel-Fourcade, M.C.; Susini, J. Micro-investigation of EPICA Dome C bottom ice: Evidence of long term in situ processes involving acid-salt interactions, mineral dust, and organic matter. Quat. Sci. Rev. 2013, 78, 248-265. [CrossRef]

11. Tison, J.L.; de Angelis, M.; Littot, G.; Wolff, E.; Fischer, H.; Hansson, M.; Bigler, M.; Udisti, R.; Wegner, A.; Jouzel, J.; et al. Retrieving the paleoclimatic signal from the deeper part of the EPICA Dome C ice core. Cryosphere 2015, 9, 1633-1648. [CrossRef]

12. Goossens, T.; Sapart, C.J.; Dahl-Jensen, D.; Popp, T.; El Amri, S.; Tison, J.L. A comprehensive interpretation of the NEEM basal ice build-up using a multi-parametric approach. Cryosphere 2016, 10, 553-567. [CrossRef]

13. Frezzotti, M.; Bitelli, G.; De Michelis, P.; Deponti, A.; Forieri, A.; Gandolfi, S.; Maggi, V.; Mancini, F.; Remy, F.; Tabacco, I.; et al. Geophysical survey at Talos Dome, East Antarctica: The search for a new deep-drilling site. Ann. Glaciol. 2004, 39, 423-432. [CrossRef]

14. Stenni, B.; Buiron, D.; Frezzotti, M.; Albani, S.; Barbante, C.; Bard, E.; Barnola, J.M.; Baroni, M.; Baumgartner, M.; Bonazza, M.; et al. Expression of the bipolar see-saw in Antarctic climate record during the last deglaciation. Nat. Geosci. 2011, 4, 46-49. [CrossRef]

15. Bazin, L.; Landais, A.; Lemieux-Dudon, B.; Toyé Mahamado Kele, H.; Veres, D.; Parrenin, F.; Martinerie, P.; Ritz, C.; Capron, E.; Lipenkov, V.; et al. An optimized multi-proxy, multi-site Antarctic ice and gas orbital chronology (AICC2012): 120-800 ka. Clim. Past 2013, 9, 1715-1721. [CrossRef]

16. Veres, D.; Bazin, L.; Landais, A.; Toyé Mahamadou Kele, H.; Lemieux-Dudon, B.; Parrenin, F.; Martinerie, P.; Blayo, E.; Blunier, T.; Capron, E.; et al. The Antarctic ice core chornology (AICC2012): An optimized multi-parameter and multi-site dating approach for the last 120 thousands years. Clim. Past 2013, 9, 1733-1748. [CrossRef]

17. Baccolo, G.; Clemenza, M.; Delmonte, B.; Maffezzoli, N.; Nastasi, M.; Previtali, E.; Maggi, V. A new method based on Low Background Instrumental Neutron Activation Analysis for major, trace and ultra-trace elements determination in atmospheric mineral dust from polar ice cores. Anal. Chim. Acta 2016, 922, 11-18. [CrossRef] [PubMed]

18. Ruth, U.; Barbante, C.; Bigler, M.; Delmonte, B.; Fischer, H.; Gabrielli, P.; Gaspari, V.; Kaufmann, P.; Lambert, F.; Maggi, V.; et al. Proxies and measurement techinques for mineral dust in Antarctic ice cores. Environ. Sci. Technol. 2008, 42, 5675-5681. [CrossRef]

19. Quartieri, S. Synchrotron Radiation in the Earth Sciences. In Synchrotron Radiation; Springer: Berlin, Germany, 2014; pp. 641-660.

20. Hawkesworth, C.J.; Kemp, A.I.S. Evolution of the continental crust. Nature 2006, 443, 811-817. [CrossRef] [PubMed]

21. Marino, F.; Castellano, E.; Ceccato, D.; De Deckker, P.; Delmonte, B.; Gheramandi, G.; Maggi, V.; Petit, J.R.; Revel-Rolland, M.; Udisti, R. Defining the geochemical composition of the EPICA Dome C ice core dust during the last glacial-interglacial cycle. Geochem. Geophys. Geosys. 2008, 9. [CrossRef] 
22. Boyd, P.W.; Ellwood, M.J. The biogeochemical cycle of iron in the ocean. Nat. Geosci. 2010, 3, 675-682. [CrossRef]

23. Wolff, E.W.; Fischer, H.; Fundel, F.; Ruth, U.; Twarloh, B.; Littot, G.C.; Mulvaney, R.; Rothlisberger, R.; de Angelis, M.; Boutron, C.F.; et al. Southern Ocean sea-ice extent, productivity and iron flux over the past eight glacial cycles. Nature 2006, 440, 491-496. [CrossRef] [PubMed]

24. Conway, T.M.; Wolff, E.W.; Röthlisberger, R.; Mulvaney, R.; Elderfield, H.E. Constraints on soluble aerosol iron flux to the Southern Ocean at the Last Glacial Maximum. Nat. Commun. 2015, 6. [CrossRef] [PubMed]

25. Baccolo, G.; Maffezzoli, N.; Clemenza, M.; Delmonte, B.; Prata, M.; Salvini, A.; Maggi, V.; Previtali, E. Low background neutron activation analysis: A powerful tool for atmopsheric mineral dust analyisis in ice cores. J. Radioanal. Nucl. Chem. 2015, 306. [CrossRef]

26. Macis, S.; Cibin, G.; Maggi, V.; Hampai, D.; Baccolo, G.; Delmonte, B.; D’Elia, A.; Marcelli, A. Microdrop deposition technique: Preparation and characterization of diluted suspended particulate samples. Condens. Matter 2018, 3, 21. [CrossRef]

27. Dent, A.J.; Cibin, G.; Ramos, S.; Smith, A.D.; Scott, S.M.; Varandas, L.; Pearson, M.R.; Krumpa, N.A.; Jones, C.P.; Robbins, P.E. B18: A core XAS spectroscopy beamline for Diamond. J. Phys. Conf. Ser. 2009, 190. [CrossRef]

28. Baccolo, G.; Delmonte, B.; Albani, S.; Baroni, C.; Cibin, G.; Frezzotti, M.; Hampai, D.; Marcelli, A.; Revel, M.; Salvatore, M.C.; et al. Regionalization of the atmospheric dust cycle on the periphery of the East Antarctic ice sheet since the last glacial maximum. Geochem. Geophy. Geosy. 2018, in press.

29. Cibin, G.; Marcelli, A.; Maggi, V.; Sala, M.; Marino, F.; Delmonte, B.; Albani, S.; Pignotti, S. First combined total reflection $\mathrm{X}$-ray fluorescence and grazing incidence $\mathrm{X}$-ray absorption spectroscopy characterization of aeolian dust archived in Antarctica and Alpine deep ice cores. Spectrochim. Acta B 2008, 63, 1503-1510. [CrossRef]

30. Marcelli, A.; Hampai, D.; Giannone, F.; Sala, M.; Maggi, V.; Marino, F.; Pignotti, F.; Cibin, G. XRF-XANES characterization of deep ice core insoluble dust. J. Anal. At. Spectrom. 2012, 27, 33-37. [CrossRef]

31. Albani, S.; Delmonte, B.; Maggi, V.; Baroni, C.; Petit, J.R.; Stenni, B.; Mazzola, C.; Frezzotti, M. Interpreting last glacial to Holocene dust changes at Talos Dome (East Antarctica): Implications for atmospheric variations from regional to hemispheric scales. Clim. Past 2012, 8, 741-750. [CrossRef]

32. Delmonte, B.; Baroni, C.; Andersson, P.S.; Shoberg, H.; Hansson, M.; Aciego, S.; Petit, J.R.; Albani, S.; Mazzola, C.; Maggi, V.; et al. Aeolian dust in the Talos Dome ice core (East Antarctica, Pacific/Ross Sea sector): Victoria Land versus remote sources over the last two climatic cycle. J. Quat. Sci. 2010, 25, 1327-1337. [CrossRef]

33. Traversi, R.; Becagli, S.; Castellano, E.; Marino, F.; Rugi, F.; Severi, M.; de Angelis, M.; Fischer, H.; Hansson, M.; Stauffer, B.; et al. Sulfate spikes in the deep layers of EPICA-Dome C ice core: Evidence of glaciological artifacts. Environ. Sci. Technol. 2009, 43, 8737-8743. [CrossRef] [PubMed]

34. Delmonte, B.; Petit, J.R.; Maggi, V. Glacial to Holocene implications of the new 27000-year dust record from the EPICA Dome C (East Atarctica) ice core. Clim. Dyn. 2002, 18, 647-660.

35. Rudnick, R.L.; Gao, S. Composition of the continental crust. In Treatise on Geochemistry; Rudnick, R.L., Ed.; Elsevier: New York, NY, USA, 2003; Volume 3, pp. 1-64.

36. Legrand, M.; Mayewski, P. Glaciochemistry of polar ice cores: A review. Rev. Geophys. 1997, 35, $219-243$. [CrossRef]

37. Rothlisberger, R.; Hutterli, A.; Sommer, S.; Wolff, E.W.; Mulvaney, R. Factors controlling nitrate in ice cores: Evidence from the Dome c deep ice core. J. Geophys. Res. 2000, 105, 20565-20572. [CrossRef]

38. Delmonte, B.; Andersson, P.S.; Shoberg, H.; Hansson, M.; Petit, J.R.; Delmas, R.; Gaiero, D.M.; Maggi, V.; Frezzotti, M. Geographic provenance of aeolian dust in East Antarctica during Pleistocene glaciations: Preliminary results from Talos Dome and comparison with East Antarctic and new Andean ice core data. Quat. Sci. Rev. 2010, 29, 256-264. [CrossRef]

39. Price, P.B. A habitat for psychrophiles in deep Antarctic ice. PNAS 2000, 97, 1247-1251. [CrossRef] [PubMed]

40. Berry, A.J.; O’Neill, H.S.C.; Jayasuriya, K.D.; Campbell, S.J.; Foran, G.J. XANES calibrations for the oxidation state of iron in a silicate glass. Am. Mineral. 2003, 88, 967-977. [CrossRef]

41. Chassé, M.; Griffin, W.L.; O’Reilly, S.Y.; Calas, G. Scandium speciation in a world-class lateritic deposit. Geochem. Perspect. Lett. 2017, 3, 105-114. [CrossRef] 
42. Johnstone, S.G.; Burton, E.D.; Keene, A.F.; Planer-Friedrich, B.; Voegelin, A.; Blackford, M.G.; Lumpkin, G.R. Arsenic mobilization and iron transformations during sulfidization of As (V)-bearing jarosite. Chem. Geol. 2012, 334, 9-24. [CrossRef]

43. Wilke, M.; Farges, F.; Petit, P.E.; Brown, G.E., Jr.; Martin, F. Oxidation state and coordination of Fe in minerals: An Fe K-XANES spectroscopic study. Am. Mineral. 2001, 86, 714-730. [CrossRef]

44. Giuli, G.; Eeckhout, S.G.; Paris, E.; Koeberl, C.; Pratesi, G. Iron oxidation state in impact glass from the K/T boundary at Beloc, Haiti, by high-resolution XANES spectroscopy. Meteorit. Planet. Sci. 2005, 40, 1575-1580. [CrossRef]

45. Formenti, P.; Caquineau, S.; Chevaillier, S.; Klaver, A.; Desboeufs, K.; Rajot, J.L.; Belin, S.; Briois, V. Dominance of goethite over hematite in iron oxides of mineral dust from Western Africa: Quantitative partitioning by X-ray absorption spectroscopy. J. Geophys. Res. Atmos. 2014, 119, 12740-12754. [CrossRef]

46. Anesio, A.M.; Laybourn-Parry, J. Glaciers and ice sheets as a biome. Trends Ecol. Evol. 2012, 27, $219-225$. [CrossRef] [PubMed]

47. Elwood Madden, M.E.; Bodnar, R.J.; Rimstidt, J.D. Jarosite as an indicator of water-limited chemical weathering on Mars. Nature 2004, 431, 821-823. [CrossRef] [PubMed]

48. Spolaor, A.; Vallelonga, P.; Cozzi, G.; Gabrieli, J.; Varin, C.; Kehrwald, N.; Zennaro, P.; Boutron, C.; Barbante, C. Iron speciation in aerosol dust influences iron bioavailability over glacial-interglacial timescales. Geophys. Res. Lett. 2013, 40, 1618-1623. [CrossRef]

(C) 2018 by the authors. Licensee MDPI, Basel, Switzerland. This article is an open access article distributed under the terms and conditions of the Creative Commons Attribution (CC BY) license (http://creativecommons.org/licenses/by/4.0/). 